\title{
SERVICE MARKETING MIX OF INDIAN HOSPITALS: A CRITICAL REVIEW
}

\author{
Dharmesh, Motwani ${ }^{1}$, Vijay, Shrimali ${ }^{2}$
}

\begin{abstract}
:
Sreenivas, Srinivasarao and Srinivasa (2013) said that "The health care market has become consumer centered and expecting high quality care at a reasonable price. The mushroomed development of corporate hospitals in India, competition is also bringing massive changes in industry structure. In this context, hospital services' marketing is slowly and surely coming of age and is being woven into the fabric of hospitals planning and public relations programmes." The essence of any marketing activity is marketing mix, and the central theme of the present paper revolves around the contemporary service marketing mix offered by Indian hospitals. In this paper author has critically reviewed 51 papers to describe elements of hospital service marketing mix; product, price, place, promotion, people, process and physical evidence.
\end{abstract}

Key words: Hospital marketing, service marketing mix, India

\section{Introduction}

Healthcare in India is one of the largest service sectors, with more than 4 million people engaged. The hospital services market represents one of the most lucrative segments of the Indian healthcare industry. The Indian hospital industry would be worth USD 280 billion by 2020 as against USD 44 billion in 2010. Various factors such as increasing prevalence of diseases, improving affordability and rising penetration of health insurance continue to fuel growth in the Indian hospital industry. One of the most important elements in human life is achieving the appropriate health care on time and this growing need of sound health has not only increased the number of hospitals and also has shaped competitive hospital industry but still there is a shortage of 4,477 primary healthcare centers and 2,337 community healthcare centers". According to "Indian Hospital Services Market Outlook" by RNCOS Industry Research Solutions, the country needs to cover the cumulative deficit of around 3 million hospital beds to match up with the global average of 3 beds per 1000 population ${ }^{* *}$. This scenario has given rise to Hospital service marketing which is a specialized field that deals with connecting patients, physicians, and hospitals in mutual relationships.

\section{Service Marketing Mix}

The essence of any marketing activity is its marketing mix which has been defined as the set of marketing tools the firm uses to pursue its marketing objective. The components of traditional marketing mix are Product, Price, Place and Promotion but while talking about hospital sector it is better to apply Service Marketing Mix which has three additional elements viz. People, Physical Evidence \& Process. Having the right marketing mix to market the services of the hospital industry is very important. Using the right balance of marketing elements, hospital service marketers can ensure that their marketing efforts fetch them expected result.

\footnotetext{
${ }^{1}$ Research Scholar, UCCMS, MLSU, Udaipur Ph. 7737976630, 9785091895, dharmeshmotwani9@gmail.com

${ }^{2}$ Prof. (Dr.), Dean and Chairman, Faculty of Commerce, UCCMS, MLSU, Udaipur Ph. 9414166499

* www.northbridgeasia.com/ResearchReports/HOSPITAL\%20RESEARCH\%20REPORT\%20\%281\%29\%20\%281\%29.pdf

** www.dinodiacapital.com/pdfs/Indian\%20Healthcare\%20Industry,\%20November\%202012.pdf
} 


\subsection{Product}

The product is the central component of any marketing mix which can be defined as a set of attributes offered to consumer. Most products of the hospitals are services which can be classified as line services, supportive services and auxiliary services. Line services which are also called core services include indoor \& outpatient services, emergency services i.e. ICU \& operation theater. Services offered by medical \& Para-medical staff come under supportive services which directly determine the quality of medical services. At last auxiliary services include ambulatory services, dietary services, indoor \& outdoor patient registration services, engineering \& maintenance services which all help in making hospital services effective.

Peters (1996) identified that hospitals are facing several threats like increasing competition, rising costs, and image problems that can threaten their existence and to face it Plsek (2003), Omachonu \& Einspruch (2010) suggested to make continues innovations in product. France \& Grover (1992) also highlighted that product differentiation is the key to marketing success $\&$ in hospitals this can be easily done by the mixing \& matching of the same set of available elements. The strong product create a different brand image of hospital and in he same line Vinodhini \& Kumar (2010) and Chao-Chan Wu (2011) established positive relationship between hospital brand image \& patient loyalty.

Sutter (2012) identified that Sustainability as a business approach is becoming widely adopted by health care companies and organizations around the world, and the easy way for all kind of hospital to become sustainable is making their product effective, Christensen, Bohmer \& Kenagy (2000) and Tiemann and Schreyögg (2009) found public hospital products more effective as compare to products of private hospitals.

\subsection{Price}

Caruana, Money \& Berthon (2000) defined price as actual charge made by a hospital and Dobson, Vanzo, Doherty, \& Tanamor (2005) Studied charge setting practices of 238 private \& public hospitals. They found that hospitals in large urban areas, and usually teaching hospitals, are more likely to consider cost information in their charge setting than their rural and non-teaching counterparts, they also identified a huge gap between charges of public \& private hospitals. Birchard et.al. (2007) and Griebl \& Skallca (2007) suggested hospital marketers to adopt transparent pricing strategy which ultimately lead to higher patient satisfaction, in the same line Consuegra, Molina and Esteban, 2007 examined the relationship between price fairness, customer satisfaction, loyalty and price acceptance. They found that price acceptance is directly influenced by satisfaction judgments and loyalty. In addition, price fairness influences price acceptance indirectly through customer satisfaction and loyalty. They suggested keeping price transparency and reliability when prices are increased.

According to Stodolak (2008) for hospital prodct pricing zero-base pricing is pricing is best method whereas Koné, Marschall and Flessa (2010) imposed on Activity-based costing method. Moliner (2009) analysed that monetary \& non monetary cost has significant impact on patient satisfaction \& loyalty towards hospital and according to Cooper (2012) hospital's costs are highly affected with the supply chain practices adopted by the hospitals, so hospital marketer should always try to purchases from manufacturer directly or take advantage of distributor schemes.

\subsection{Place}

Place refers to the contact point between health service provider \& patient. This element of marketing mix leads to the identification of suitable location. For effective distribution of Medicare services it is essential that the hospitals should be able to provide 
basic medical services at different parts of residential areas and also to rural areas in particular, furthermore Hospital should be located somewhere which is easily accessible by patients and transport services are also available for them easily

John, Yorgos, Kerasia, Nadia, \& Panos (2008) suggested that while selecting location for any clinic or hospital spatial analysis of GIS method should be adopted, on the other hand Lin, Lee and Chen (2010) pointed out that an appropriate medical region must be selected before establishing a new hospital so recommended data envelopment analysis (DEA) method to establish the effective indicators, and to identify medical areas lacking medical resources and where there is relatively less competition

Miller (2010) said that in past, a hospital could rely on its location for a stable client base but practically there are limitations to the degree of physical changes which can be made to an existing building (Pitt, 1993) so according to Goldstein, Ward, Leong, \& Butler (2002) hospitals can moderate the effect of location by investing more extensively in clinical technologies tend to be better performance.

\subsection{Promotion}

Promotion activities of a hospital helps in communicating the existence of services offered to present, past \& future customers. Generally promotion includes advertising, sales promotion, personal selling \& publicity, but instead of undertaking aggressive promotion, hospitals rely lot on WOM (Shoqirat \& Cameron, 2012) \& social marketing (Evans, 2006). Lynch and Schalet (1999) pointed out that hospital advertisements should contain a relatively high level of information and should be advertised as comfort zones for human ailments (Gangopadhyay and Bandopadhyay 2012).

According to Reddy and Campbell (1993), Positioning is effective marketing strategic tools that can help a hospital compete for market share and revenues more effectively. In developing strategies, a hospital must first assess a community's health needs, establish the hospital's current and desired positions on its segments' perceptual maps, and finally, choose and implement appropriate positioning strategies. Johnson \& Baum (2001) suggested that instead of doing hospital promotion, marketer should focus on health education which can position the image of hospital in the mind of patients and in turn increase its market share.

\subsection{People}

Hospital industry is a knowledge based industry, so people play key role in hospitals which include doctors, nursing staff, paramedical staff, supporting staff \& front office executives. Kabene, Orchard, Howard, Soriano and Leduc (2006) concluded that Proper management of human resources is critical in providing a high quality of health care as 'doctor concern' (Laohasirichaikul, Chaipoopirutana and ombs 2009) and nurse-client interaction (Korsah 2011) are the most important factor affecting customer satisfaction. Following factors should be considered as part of the recruitment process of medical staff:

a) Emotionally stable individuals having inclination for good service (Lanjananda \& Patterson 2009)

b) Caring nature ( Dhanda and Kurian 2012)

Ceyhun, Cagatay, Alper and Meltem (2012) indicated that unavailability of doctors and nurses, as well as their negative attitudes and behaviors, are major barriers to the utilization of public and private hospitals. Winsted (2000) supported the notion that Patients want doctors to demonstrate concern and competence, be congenial, communicate with them, be courteous, and be civil. Successful implementation of these behaviors by service personnel could be a very useful tool for medical providers to ensure customer satisfaction and retention. 


\subsection{Physical Evidence}

Physical evidence of a hospital includes all the physical or tangible commodities which provide a tangible aspect to the intangible services. According to Babu and Rajalakshmi (2009) It is necessary for a hospital to be well organized and Special care should be taken to maintain hygienic, cleanliness and whole hospital must be well lit Physical evidence particularly plays an important role in the hospital where the patients are already depressed or traumatized and a good atmosphere could make all the difference. Reiling (2005) suggested that while designing a hospital facility it should be engineered properly as Holder (2008) concluded that physical evidence is an important dimension in the perception of service quality for patients in health sector. Review has identified following important aspects of physical evidence:

- Physical design of the hospital (Angood et.al. 2008)

- Amenities, signs, symbol, and artifacts (Laohasirichaikul, Chaipoopirutana and Combs, 2009)

- Ambient conditions (Pollack, 2009)

- General condition of equipment and neat appearance of staff members (Jager \& Plooy, 2011)

- Energy Efficiency and Indoor Air Quality (Khalil, 2012)

\subsection{Process}

Process is defined as an operational flow of activities which are taken place at hospital for the efficient delivery of services. Following attributes of process leads to patient satisfaction:

- Least difference between perceived waiting times and expected waiting time (Davis and Heineke 1998)

- Choice of physician (Amyx and Bristow 2001)

- Appropriate use of patient safety measures \& patient education (McFadden, Stock and Gowen 2006) and (Assefa1, Woldie, Ololo and Woldemichael 2012)

Kripalani, Jackson, Schnipper \& Coleman (2007) identified that the transition from hospital to home is a vulnerable period of discontinuity and potential adverse events. Hospitalists and other inpatient providers should not view discharge as an end to their obligation to patients but rather should attempt to promote a safe and efficient transition of care. Narang (2010) concluded that health care delivery is statistically significant in impacting the perception of respondents, so it should be improved continually.

\section{Conclusion}

After the thorough review of available literature, it is abundantly clear that Service Marketing Mix is of great importance in today's Hospital Industry and is the best tool to be innovative in the industry. With the growing importance of service marketing mix, hospital administrators are becoming increasingly marketing oriented. All the above service marketing mix elements revolve around customers. In hospital service price transparency, placing hospital services at convenient location of patients, behavior of medical staff, tangibility and process through technology plays important role in differentiating services from competitors.

\section{References}

1. Amyx, D., \& Bristow, N.D. (2001). An empirical investigation of customer satisfaction with health care services. Marketing Intelligence \& Planning, 19(7), 515-525.

2. Angood et. Al. (2008). Guiding Principles for the Development of the Hospital of the Future. 1-45. 
3. Assefa1, T., Woldie, M., Ololo, S., \& Woldemichael, K. (2012). Patient safety practices and medical errors: Perception of health care providers at Jimma University Specialized Hospital, Southwest Ethiopia. Open Journal of Preventive Medicine, 2(2), 162-170.

4. Babu S., and Rajalakshmi, K. (2009). Marketing Mix for Hospital Services in the Globalized Era. Retrieved from http://www.indianmba.com/Faculty_Column

5. Birchard et.al. (2007). Health Care Price Transparency. Deloitte Center for Health Solutions, 1-24.

6. Caruana, A., Money, H.A. \& Berthon, R.P. (2000). Service quality and satisfaction - the moderating role of value. European Journal of Marketing, 34(11/12), 1338-1352.

7. Ceyhun, C.K., Cagatay, U., Alper, A. \& Meltem, I. (2012). A Study On The Evaluation Of The Customers Satisfaction In Hospitals. Clute Institute International Conference, June 2012, 431-435

8. Chao-Chan, Wu (2011). The impact of hospital brand image on service quality, patient satisfaction and loyalty. African Journal of Business Management, 5(12), 4873-4882.

9. Christensen, M.C., Bohmer, R. \& Kenagy, J. (2000). Will Disruptive Innovations Cure Health Care. Harvard Business Review, Sep.-Oct. 2000, 1-10.

10. Consuegra, D.M., Molina, A., \& Esteban, A. (2007). An integrated model of price, satisfaction and loyalty: an empirical analysis in the service sector. Journal of Product \& Brand Management, 16(7), 459-468

11. Cooper, P. (2012). Hospital Procurement Study. HIDA Educational Foundation, 1-16.

12. Davis, M.M., \& Heineke, J. (1998). How disconfirmation, perception and actual waiting times impact customer satisfaction. International Journal of Service Industry Management, 9(1), 64-73.

13. Dhanda, K.K., \& Kurian, S. (2012). An Exploratory Study on Hospital's Staff with their Patient Satisfaction. Indo Global Journal of Pharmaceutical Sciences, 2(2), 197-202.

14. Dobson, A., Vanzo, J., Doherty, J., \& Tanamor, M. (2005). A Study of Hospital Charge Setting Practices. MedPAC, 05(4), 1-29.

15. Evans, W.D. (2006). How Social Marketing Works In Health Care. British Medical Journal, 332(7551), 207-1210.

16. France, R.K., \& Grover, R. (1992). What Is the Health Care Product? Journal of Health Care Marketing, 12(2), 31-38.

17. Gangopadhyay, S., \& Bandopadhyay, P. (2012). Hospital Advertising: Myth or Reality. Indian Journal of Marketing, June 2012, 47-53.

18. Goldstein, S.M., Ward, P.T., Leong, G.K., \& Butler, T.W. (2002). The effect of location, strategy, and operations technology on hospital performance. Journal of Operations Management, 20, 63-75

19. Griebl, O., \& Skallca, C. (2007). The growing imperative of effective pricing strategies and tools for not-for-profit hospitals. Healthcare Financial Management. October 2007, 76-80.

20. Holder, S.M. (2008). Changes in Physical Evidence and the perception of Service Qality of Patients in a Hospital Facility. The university of Johannesburg, October 2008.

21. Jager, J., \& Plooy, T. (2011). Tangible Service-Related Needs of Patients in Public Hospitals in South Africa. The $2^{\text {nd }}$ International Research Symposium in Service Management. 418-428.

22. John, K., Yorgos, P.N., Kerasia, M., Nadia, B., \& Panos, M. (2008). Primary care clinic location decision making and spatial accessibility for the region of Thessaly. Health Science Journal, 2(1), 20-24

23. Johnson, A., \& Baum, F. (2001). Health promoting hospitals: a typology of different organizational approaches to health promotion. Health Promotion International, 16(3), 281-287.

24. Kabene, M.S., Orchard, C., Howard, M.J., Soriano, A.M. \& Leduc, R. (2006). The importance of human resources management in health care: a global context. Human Resources for Health 4:20

25. Khalil, E.E. (2012). Energy Efficient Hospitals Air Conditioning Systems. Open Journal of Energy Efficiency, 1, 1-7.

26. Koné, I., Marschall, P., \& Flessa, S. (2010). Costing of Malaria treatment in a rural district hospital. Health, 2(7), 759-768. 
27. Korsah, A. K. (2011). Nurses' stories about their interactions with patients at the Holy Family Hospital Techiman, Ghana. Open Journal of Nursing, 1, 1-9.

28. Kripalani, S., Jackson, A.T., Schnipper, J.L., \& Coleman, E.A. (2007). Promoting Effective Transitions of Care at Hospital Discharge: A Review of Key Issues for Hospitalists. Journal of Hospital Medicine, 2, 314-323

29. Lanjananda, P., \& Patterson, G.P. (2009). Determinants of customer-oriented behavior in a health care context. Journal of Service Management 20(1), 5-32

30. Laohasirichaikul, B., Chaipoopirutana S., \& Combs, H. (2009). Effective customer relationship management of health care: a study of hospitals in Thailand. Journal of Management and Marketing Research, 1-12.

31. Laohasirichaikul, B., Chaipoopirutana S., \& Combs, H. (2009). Effective customer relationship management of health care: a study of hospitals in Thailand. Journal of Management and Marketing Research, 1-12.

32. Lin, C.T., Lee, C., \& Chen, Z.J. (2010). An Expert System Approach to Medical Region Selection for a New Hospital Using Data Envelopment Analysis. iBusiness, 2, 128-138.

33. Lynch, J., \& Schalet, D. (1999). Consumer Evaluation of the Quality of Hospital Services From an Economics of Information Perspective. JHCM, 19(2), 16-22

34. McFadden, L.K., Stock, N.G., \& Gowen, III R., C. (2006). Implementation of patient safety initiatives in US hospitals. International Journal of Operations \& Production Management, 26(3), 326-347.

35. Miller, H. (2010). Patient Rooms: A Changing Scene of Healing. Healthcare, 1-10

36. Moliner, A.M. (2009). Loyalty, perceived value and relationship quality in healthcare services. Journal of Service Management, 20(1), 76-97.

37. Narang, R. (2010). Measuring perceived quality of health care services in India. International Journal of Health Care Quality Assurance, 23(2), 171-186.

38. Omachonu, V.K., \& Einspruch, N.G. (2010). Innovation in Healthcare Delivery Systems: A Conceptual Framework. The Innovation Journal: The Public Sector Innovation Journal, 15(1), 1-20.

39. Peters, M.P. (1996). Innovation for hospitals: an application of the product development process. JHCM, 6(3), 52-59.

40. Pitt, C. (1993). Quality Health Care: Identifying and Meeting Customer Needs. International Journal of Health Care Quality Assurance, 6(6), 25-28.

41. Plsek, P. (2003). Complexity and the Adoption of Innovation in Health Care. National Institute for Health Care Management Foundation, Washington.

42. Pollack, B.L. (2009). Linking the hierarchical service quality model to customer satisfaction and loyalty. Journal of Services Marketing, 23(1), 42-50.

43. Reddy, C.A., \& Campbell, P.D. (1993). Positioning Hospitals: A Model for Regional Hospitals. Journal of Health Care Marketing, winter 1993, 40-44.

44. Reiling, G.J.(2005). Creating a Culture of Patient Safety through Innovative Hospital Design. Advances in Patient Safety, 2, 426-439.

45. Shoqirat, N., \& Cameron, S. (2012). Promoting Hospital Patients' Health in Jordan: Rhetoric and Reality of Nurses' Roles. International Journal of Nursing, 1(1), 28-37

46. Sreenivas T., Srinivasarao B. and Srinivasa Rao U (2013). An Analysis on Marketing Mix in Hospitals. Advances in Management, 6(2), 46-55

47. Stodolak, F. (2008). Hospital zero-base pricing can make a difference. Healthcare Financial Management, September 2008, 102-108.

48. Sutter, K. (2012). The Growing Importance of More Sustainable Products in the Global Health Care Industry. Johnson \& Johnson, 1-16.

49. Tiemann, O., \& Schreyögg, J. (2009). Effects of Ownership on Hospital Efficiency in Germany. BuR - Business Research Official Open Access Journal of VHB, 2 (2), 115-145.

50. Vinodhini, Y., \& Kumar, B.M. (2010), Brand Equity in Hospital Marketing. Summer Internship Society 2 (1), 89-93.

51. Winsted, F.K. (2000). Patient satisfaction with medical encounters a cross-cultural perspective. International Journal of Service Industry Management, 11(5), 399-421. 